Accepted for publication in Journal of Population Economics.

Please cite as: Baert, S., Vujić, S. (in press): Does it Pay to Care? Volunteering and

Employment Opportunities? Journal of Population Economics.

\title{
Does it Pay to Care? Volunteering and Employment Opportunities*
}

\author{
By Stijn Baerti and Sunčica Vujićii
}

\begin{abstract}
We investigate whether volunteering has a causal effect on individual employment opportunities. To this end, a field experiment is conducted in which volunteering activities are randomly assigned to fictitious job applications sent to genuine vacancies in Belgium. We find that volunteers are 7.3 percentage points more likely to get a positive reaction to their job applications. The volunteering premium is higher for females but invariant with respect to the number of engagements.
\end{abstract}

Keywords: volunteering; labour market; statistical discrimination; experiments.

JEL: C93; D64; J24; J71.

\footnotetext{
* Acknowledgements. We would like to thank Koen Van De Velde and Morgane Vercruysse for their excellent research assistance. In addition, we are grateful to editor Erdal Tekin, three anonymous reviewers and the participants of the WM workshop at the University of Lille, the 2017 Royal Economic Society Annual Conference the 31st Annual Conference of the European Society for Population Economics and the 29th conference of the European Association of Labour Economists for their valuable comments to earlier versions of the manuscript and for their constructive suggestions.

' Corresponding author. Ghent University, University of Antwerp, Université catholique de Louvain, GLO and IZA. Sint-Pietersplein 6, B-9000 Ghent, Belgium. Stijn.Baert@UGent.be. http://users.UGent.be/ sbaert.

ii University of Antwerp and University of Bath. Prinsstraat 13, B-2000 Antwerp, Belgium.
} 


\section{Introduction}

Volunteering is a widespread phenomenon in OECD countries. On average, $23.4 \%$ of respondents in the sixth round of the European Social Survey (ESS6) in 2012/2013 reported that they were involved in work for voluntary or charitable organisations at least once every six months. As seen in Figure 1, statistics on volunteering in Europe are both stable over time and heterogeneous across countries. Whereas in 2012/2013 in Germany, the Netherlands, Norway and Switzerland, more than 40\% of ESS6 respondents volunteered, in Bulgaria and Hungary, less than 10\% engaged at least once every sixth months in volunteer work. Given the substantial amount of engagement as a volunteer, economists have unsurprisingly shown a renewed interest over the past decade in the economic consequences of these types of activities, from both society's and individuals' point of view (see, e.g., Binder and Freytag, 2013; Carpenter and Myers, 2010; Cozzi et al., in press; Meier and Stutzer, 2008; Sauer, 2015). In the present study, we focus on the causal effect of volunteering with respect to individuals' (paid) employment opportunities.

\section{FIGURE 1 ABOUT HERE.}

Theoretically, there are three likely channels through which volunteering might affect one's labour market outcomes: human capital, social capital and employer preferences. Based on these channels, both beneficial and adverse effects of volunteering on employment outcomes are possible. First, volunteer work may directly enhance individuals' human capital by providing them with an alternative way to acquire skills and experience. Following standard Human Capital Theory (Becker, 1964; Mincer, 1958), these skills and experience may lead to additional returns on the labour market (Becker, 1964; Day and Devlin, 1997; Day and Devlin, 1998). However, based on the same theory in combination with the Theory of the Allocation of Time (Becker, 1965), a negative effect might also be expected because maintaining substantial volunteering schemes may interfere with time investments in hard skills. Second, according to Social Network Theory (Granovetter, 1973), during volunteer work, socially engaged people may expand their networks, which 
might help them find a better job match more quickly (Sauer, 2015). Thirdly and finally, volunteering might affect employers' hiring and promotion decisions even when volunteering activities do not affect employees' human or social capital. On the one hand, following Becker's (1957) taste-based discrimination model, employers may prefer (not) to hire job candidates with volunteering activities just because these employers, their co-workers or customers experience a certain (dis)utility from working together with these prosocially engaged people. On the other hand, following Arrow's (1973) model of statistical discrimination, employers might use social engagement on applicants' résumés to screen and sort job seekers according to abilities that are unobserved by these employers. In this respect, social engagement is related in the peer-reviewed literature to personality traits such as emotional stability, extraversion and openness, which are shown to enhance individual productivity and team performance (Barrick and Mount, 1991; Bekkers, 2005; Besley and Ghatak, 2005; Borghans et al., 2008; Costa and McCrae, 1992; Elshaug and Metzer, 2001; Gregg et al. 2011; Fortin, 2008; Heineck, 2011; Lagarde and Blaauw, 2014; OECD, 2015; Tett et al., 1991; Uysal and Pohlmeier, 2011). However, volunteering might also be perceived as a signal of a lower focus on regular employment given the aforementioned time trade-off between volunteering activities and regular work.

We are aware of seven previous studies by economists that confronted the aforementioned theoretical expectations with the empirical reality: Day and Devlin (1997), Day and Devlin (1998), Prouteau and Wolff (2006), Hackl et al. (2007), Sauer (2015), Wilson et al. (2017) and Cozzi et al. (in press). Table 1 summarises the research results published, between 1997 and 2017, either as a journal article or as a working paper. As shown in Table 1, these studies were conducted based on observational data for Austria, Canada (two studies), France, the United Kingdom (two studies) and the United States. Most of them apply micro-econometric techniques, which are described in the last column of Table 1, to control for unobserved determinants of both volunteering and labour market outcomes. Remarkably, all these studies found statistically significantly positive effects of 
volunteer work on income. ${ }^{1}$ However, this premium varied considerably, i.e. from $2.6 \%$ to $94.7 \%$.

\section{TABLE 1 ABOUT HERE.}

In the present study, we complement this empirical evidence by measuring the premium of volunteering with respect to an alternative labour market outcome, i.e. employment opportunities. Thereby, we explore a potential reason for the positive association between volunteering and income reported in the literature, i.e. the access to a (potentially better paid) job. To this end, we provide the first (field) experimental estimates on the labour market returns to volunteering. More concretely, we run a randomised field experiment in which pairs of fictitious job applications are sent to real vacancies. For each vacancy, one of the two applications is randomly assigned to a treatment of volunteering. Due to this experimental design, selection into volunteering on the basis of individual unobservable characteristics is eliminated because the researcher controls all the information received by the employer. Therefore, unequal treatment of volunteers and nonvolunteers can be due only to their revealed social engagement.

Moreover, our research design enables us to provide suggestive evidence with respect to heterogeneous treatment effects of volunteering. First, we inspect whether the returns to volunteering in hiring are heterogeneous by gender. Former empirical evidence on gender differentials indicates higher premiums for males. Day and Devlin (1997), Wilson et al. (2017) and Cozzi et al. (in press) found that men have larger returns to volunteer experience than women and that these differential returns can explain a substantial part of the gender earnings gap. Thanks to our experimental setting, in which we alternate between female and male pairs, we are able to investigate whether there is also a higher premium of volunteering for males with respect to hiring chances. Second, our experimental design allows us to investigate the relative effect of different doses of volunteer work (i.e. one, two or three volunteering activities). More activity might yield a stronger signal of

\footnotetext{
${ }^{1}$ One exception is the finding of a decrease in current earnings by $1.7 \%$ for volunteers in the subgroup of workers in the private sector in France (Prouteau and Wolff, 2006).
} 
(beneficial qualities related to) volunteering and a stronger signal of an overly low focus on paid regular work (given the aforementioned time trade-off between both activities).

\section{The Experiment}

To measure the volunteering premium in employment opportunities, we built on the correspondence experimentation framework of Bertrand and Mullainathan (2004), which has been recently used and calibrated by Kroft et al. (2013), Eriksson and Rooth (2014), Patacchini et al. (2015) and Baert et al. (2016c), among others. Within this type of experiment, pairs of fictitious job applications are sent to real job openings. The fictitious applications only differ in the characteristic (the experimental "treatment") that is to be tested. By monitoring subsequent call-back, unequal treatment based on this characteristic ("treatment effect") can be identified and given a causal interpretation (Pager, 2007; Riach and Rich, 2002).

We conducted our experiment between December 2014 and April 2015. During this period, we sent pairs of fictitious job applications to real vacancies in Flanders, the Northern part of Belgium, ${ }^{2}$ posted by commercial and non-commercial organisations. For each vacancy, we randomly assigned two identities with respect to volunteering (one control and one treated identity) to each member of the pairs of applicants. In addition to this within-pair randomisation of volunteering, to inspect heterogeneous treatment effects, the female or male gender (equal for both pair members) and different combinations of three types of volunteering (for the treated applicant within the pairs) were randomly assigned between the pairs of applicants. Thereafter, reactions from the employers were analysed to investigate the surplus ${ }^{3}$

\footnotetext{
${ }^{2}$ Based on the ESS6 data mentioned in the introduction, the level of volunteering in Belgium is slightly above the average level across all respondents in Europe. More concretely, 27.0\% of the surveyed Belgians in the ESS6 data reported having undertaken volunteer work during the previous six months (see Figure 1).

${ }^{3}$ Throughout this article, with the "surplus of volunteering", we refer to job candidates' higher probability of positive
} 
from different types of volunteering for different types of individuals.

\subsection{Application Templates}

In contrast to many former correspondence experiments in which applications were sent to vacancies in only one or a few specific occupations (with, potentially, a high (or low) treatment effect) (Baert, 2017), ${ }^{4}$ we aimed to test the returns to volunteering with respect to hiring chances in multiple occupations (and, in relation to this, multiple sectors). Therefore, we created pairs of application templates (comprised of a résumé and a motivation letter) for jobseekers at two education levels. The middle-educated pair held a secondary education degree in commerce, and the high-educated pair held a bachelor's degree in office management. These degrees, obtained from the same type of school, allowed them to apply for almost all commercial and administrative positions at the ISCED 3 and ISCED 5 levels, ${ }^{5}$ respectively.

The two templates within each pair (which we labelled type ' $A$ ' and type ' $B$ ' applications) were, at the education level, identical concerning all job-relevant characteristics but differed in wording, fonts and formatting to prevent the employers from detecting the experiment. To ensure that our templates were realistic, example résumés and motivation letters from the Public Employment

\footnotetext{
call-back due to volunteer work disclosed in their résumés.

${ }^{4}$ For instance, age discrimination is tested by Riach and Rich (2007) in the occupation of waiter only, by Albert et al. (2011) in the occupations of seller and waiter only and by Ahmed et al. (2012) in the occupation of clerk (in accountancy, administration or sales) only.

${ }^{5}$ ISCED stands for "International Standard Classification of Education". ISCED 3 refers to upper-secondary education (i.e. more specialised education that typically begins at age 15 or 16 years preparing; it prepares pupils for tertiary education, provides them with skills relevant to employment, or does both). Examples of tested occupations at this level are: administrative clerk, call center employee, commercial clerk, demonstrator, executive clerk, representative, and (tele-)seller. ISCED 5 refers to the first stage of tertiary education (i.e. programmes with an educational content more advanced than those offered at ISCED level 3 and ISCED level 4 (post-secondary nontertiary education), which might be academically or practically oriented). Examples of tested occupations at this level are: (assistant) accountant, consultant in marketing and publicity, consultant in finance, consultant in recruitment and selection, customer declaration officer, and executive assistant human resources.
} 
Agency of Flanders ("VDAB") were used and refined.

All fictitious applicants were single individuals born, living and studying in Antwerp, the largest city of Flanders, with approximately 503,000 inhabitants. The middle-educated individuals were 20 years old, and the high-educated were 23 years old. They graduated in June 2012. Between August 2012 and November 2014 (just before the start of our experiment), they were employed in an administrative position at the level of their educational degree. At the moment of application, all applicants were unemployed and actively looking for a new job. A reason for the termination of their first job was not provided in the applications.

In addition, the following characteristics were added to all fictitious applicants: a Flemish name and surname; ${ }^{6}$ an address (existing street name but non-existing house number) in a middle income neighbourhood; an email address and a mobile phone number (from leading providers); a date of birth in 1994 (middle-educated) or 1991 (high-educated); a gender (see Section 2.2); a Belgian nationality; very good Dutch, French and English language skills; very good office software skills; a driver's license; and the availability of a car.

It is important to keep in mind that minimal differences between type $A$ and type B application templates could not bias our results because the volunteering engagement as our treatment of interest was, for each vacancy, randomly assigned to these types, as discussed in the following subsection.

\subsection{Randomised Assignment of Treatment of Volunteering, Particular Combination of Volunteer Work and Gender}

Two job candidacies, one of type $A$ and one of type $B$, were sent to each selected vacancy. Within these pairs of applicants, the mention of undertaken volunteer work was alternately assigned to either the type A template or the type B template. More specifically, volunteer work was mentioned in the résumés" "Miscellaneous" section,

\footnotetext{
${ }^{6}$ In parallel with this field experiment, an analogous experiment was conducted with Turkish names to investigate whether volunteering might reduce ethnic labour market discrimination (Baert and Vujić, 2016).
} 
in which it is common in Flanders to refer to "extracurricular" memberships and engagements. Résumés that did not have volunteer work only reported their car ownership under the "Miscellaneous" section.7

To measure the returns to volunteering for different types and different doses of volunteer work, we alternately assigned one out of seven combinations of volunteer activities to the treated applicant. These seven options were based on all possible combinations of one, two or three engagements out of three potential activities. The first activity that was mentioned by a part of the treated applicants was "volunteer work at Poverello [the major life-saving food provider in Belgium] (preparing and disseminating meals, once per week)." The second potential activity was "volunteer work at Stichting tegen Kanker [the major cancer foundation in Belgium] (fundraising and supporting local activities on a frequent basis)." The last one was "equipment manager at Korfbal Club Artemis [a regional korfball club in Antwerp] (logistic support at main trainings and game days).." Consequently, the seven possible combinations that were alternately revealed by the treated applicants were: (i) volunteer at life-saving food provider; (ii) volunteer at cancer foundation; (iii) volunteer at sports club; (iv) volunteer at life-saving food provider and cancer foundation; (v) volunteer at life-saving food provider and sports club; (vi) volunteer at cancer foundation and sports club, and (vii) volunteer at life-saving food provider, cancer foundation and sports club.

Finally, to obtain heterogeneous volunteering effects by gender, we alternated between female and male pairs of fictitious candidates. The gender of the candidates was indicated in the résumé by means of their name and gender. Their (typically male or female) name was also mentioned in their motivation letter.

\footnotetext{
${ }^{7}$ As mentioned earlier, $23.4 \%$ of all European and $27.0 \%$ of all Belgian respondents in the ESS 6 reported that they were involved in volunteer work. When focussing only on the subpopulation of interest for our study, i.e. youth respondents, the corresponding percentage is $24.0 \%$ for the 15 - to 24 -year-olds both in Europe and Belgium. So, volunteer work is more or less as common for young people as for adults.

${ }^{8}$ This sports was chosen due to its high representation of both females and males.
} 


\subsection{Vacancy Selection, Application and Call-Back}

We sent to genuine vacancies the resulting combinations of two application templates, two experimental identities, seven combinations of different types and doses of volunteer work, and two genders. These two applications were sent with 12 to 36 hours in between and in an alternating order. More concretely, between December 2014 and April 2015, we tested randomly selected vacancies in the database of the Public Employment Agency of Flanders, the region's major job search channel, for which our (middle- or high-educated) pairs of applicants had the right classifications. In total, we sent out 576 applications; half of them were with middle-educated applicants, and the other half were with high-educated applicants.

Reactions from (real) employers to our fictitious candidacies were received by email and mobile phone voicemail. All reactions obtained later than 40 days after the date of candidacy submission were not considered. In our analysis, we will distinguish between two definitions of positive call-back. Positive call-back in a broad sense indicates that the applicant received (i) an invitation for an interview concerning the job for which she/he applied, (ii) a proposal of an alternative position, (iii) an inquiry to provide the employer with more information, or (iv) a general inquiry to contact the employer. Positive call-back in a strict sense indicates that the applicant was invited for an interview concerning the job for which she/he applied. ${ }^{9}$ As we measure (and analyse) only these very first call-backs, our results discussed in the following section should not be equated to divergences in final job offers (let alone in wages or income). We return to this limitation in Section 4.

\footnotetext{
${ }^{9}$ By presenting both outcomes, we pursue to be as complementary to the literature as possible. A substantial proportion of correspondence studies only provide statistics on positive call-back in a broad sense (Albert et al., 2011; Jacquemet and Yannelis, 2012; Kaas and Manger, 2012; Patacchini et al., 2015) while another substantial proportion only focuses on interview rates (Ahmed et al., 2012; Bertrand and Mullainathan, 2004; Eriksson and Rooth, 2014; Kroft et al., 2013; Riach and Rich, 2007). Some recent contributions present both outcome measures, as we do (Baert et al., 2016a; Baert et al., 2016b; Lahey, 2008; Neumark et al., 2015).
} 


\section{The Results}

\subsection{Bivariate Analysis}

Table 2 describes our data. We present positive call-back rates for the volunteering and non-volunteering candidate within the submitted pairs of fictitious job candidacies. In Panel A (Panel B) we list these outcomes for the broad-sense (strictsense) definitions of positive call-back, respectively.

\section{TABLE 2 ABOUT HERE.}

Call-back outcomes with respect to all tested vacancies together are presented in the first row of Panel A and Panel B. Overall, the volunteering candidates received a positive reaction in a broad sense (an invitation for a job interview) in $22.9 \%$ (11.1\%) of applications, whereas their non-volunteering counterparts obtained a positive reaction (an invitation) in only $15.6 \%\left(8.3 \%\right.$ ) of cases..$^{10}$ The positive call-back difference between these "treated" and control candidates is presented in column (5). The volunteering candidate within the pairs of fictitious candidates was 7.3 percentage points more likely to receive any positive reaction and 2.8 percentage points more likely to being invited for a job interview. ${ }^{11}$ The former statistic is significantly different from 0 at the $1 \%$ significance level. The latter is significant only at the $10 \%$ significance level, related to the lower level of variation in positive callbacks in a strict sense.

Somewhat surprisingly, this overall level of the hiring premium for volunteers is only slightly smaller than the level of the premium of a native-sounding (versus a

\footnotetext{
${ }^{10}$ Broken down by the four categories of positive call-back mentioned at the end of Section 2.3, the volunteering candidates got, besides an interview invitation in $11.1 \%$ of the cases (32 vacancies), a proposal of an alternative position in $1.4 \%$ of the cases ( 4 vacancies), an inquiry to provide the employer with more information in $3.5 \%$ of the cases (10 vacancies) and a general inquiry to contact the employer in 6.9\% of the cases (20 vacancies). The control candidate got, besides an interview invitation in $8.3 \%$ of the cases (24 vacancies), a proposal of an alternative position in $0.3 \%$ of the cases ( 1 vacancy), an inquiry to provide the employer with more information in $2.4 \%$ of the cases (7 vacancies) and a general inquiry to contact the employer in $4.5 \%$ of the cases (13 vacancies).

${ }^{11}$ Stated otherwise, volunteers are $46.7 \%(\approx 0.229 / 0.156)$ more likely to get positive call-back in a broad sense and $33.3 \%(\approx 0.111 / 0.083)$ more likely to get positive call-back in a strict sense compared to non-volunteers.
} 
Turkish-sounding) name found within a comparable correspondence study in Flanders in 2011-2012 on ethnic discrimination (with a positive call-back difference of 8.0 and 5.8 percentage points with respect to getting any positive reaction and getting an invitation to a job interview, respectively; Baert et al., 2015). In addition, the surplus from volunteering is comparable to the surplus found for male applicants (compared to female applicants) when applying for positions implying a first promotion in a comparable experiment on Sticky Floors in the Flemish labour market in 2013-2014 (with a premium of 4.9 and 3.7 percentage points with respect to getting any positive reaction and getting an invitation to a job interview, respectively; Baert et al., 2016a).

In the lower rows of Panel A and Panel B of Table 2, we break down the positive call-back differences by several characteristics of the pairs of fictitious candidates. More concretely, we break down the total sample by (i) the education level of the pair, (ii) the pair's gender, (iii) the mention of a particular type of volunteer work by the treated pair member and (iv) her/his total number of volunteering activities mentioned. First, our overall finding of a surplus for volunteering at first hiring decisions is somewhat driven by the subsample of high-educated individuals. However, while the volunteering premium in both subsamples by this break down is (weakly) significant with respect to positive call-back in a broad sense, they are both insignificant with respect to positive call-back in a strict sense. Second, we find suggestive evidence for the volunteering premium to be higher for female than for male candidates. For female candidates, the mention of an engagement as a volunteer increases the probability of a positive reaction by 13.2 percentage points and the probability of a job interview invitation by 6.9 percentage points. For the subsample of male candidates, no unequal treatment based on volunteering is found. This higher call-back premium for women contrasts with the research findings of Day and Devlin (1997), Wilson et al. (2017) and Cozzi et al. (in press) mentioned in the introduction. We return to this observation in Section $4 .{ }^{12}$ Third, positive call-

\footnotetext{
12 In addition, breaking down our data by the gender of the candidates indicates that Belgian employers prefer female workers in the tested occupations. This might be related to the fact that these occupations are female-
} 
back rates are somewhat higher for pairs in which the treated candidate revealed (solely or together with one or both of the two other volunteering activities) volunteering at the life-saving food provider or at the cancer foundation (compared to revealing volunteering at the korfball club). Fourth, the last rows in Panel A and Panel B do not provide evidence for a higher volunteering premium for volunteers with more volunteering activities. ${ }^{13}$ We will return to the significance of all these dimensions of heterogeneity in the premium of volunteering with respect to first hiring outcomes when we present our regression results in the next subsection.

\subsection{Multivariate Analysis}

Because the volunteering and non-volunteering candidates were randomly assigned within our pairs of applications, regressing positive call-back on an indicator of being a volunteering candidate yields exactly the same empirical pattern as that based on the first row of Panel A and Panel B of Table 2. Moreover, because these variables were randomly assigned between pairs, regressions on interactions between volunteering and, among other candidate characteristics, the gender of the candidate and her/his particular volunteer work should lead to the same empirical pattern as the one in the lower rows of Panel A and Panel B of Table 2, at least when the sample size approaches infinity. However, the actual size of our sample is not infinite. Consequently, some of the variables randomly assigned between pairs may happen to correlate with vacancy characteristics such as the sector or the use of an interim office. Moreover, by construction, the type and dose of the mentioned volunteering are correlated with each other. ${ }^{14}$ To control for these sources of

\footnotetext{
dominated. Because typically female characteristics are perceived as particularly productive in traditionally female occupations, hiring outcomes are expected to be more in favour of women in these female-dominated occupations (Baert et al., 2016a; Booth and Leigh, 2010; Weichselbaumer, 2004).

${ }^{13} \mathrm{An}$ important caveat in this respect is that we might have lacked statistical power to reject unequal treatment for the subsamples of vacancies in which the treated candidate revealed only one volunteering activity (96 vacancies) or three volunteering activities (48 vacancies).

${ }^{14}$ In case one (two; three) engagement(s) is (are) mentioned, the probability for each particular type to be included in the résumé is $33.3 \%(66.7 \% ; 100.0 \%)$.
} 
correlation, we further analyse the experimental data by a regression analysis.

Table 3 presents our model estimates. We regress positive call-back in a broad sense (Model (1) to (4)) or a strict sense (Model (5) to (8)) on various sets of key and control variables, included as such (when not invariant for control applicants) and in interaction with disclosing an engagement as a volunteer. To ensure comparability of the average volunteering effect across regression models, all variables except for the one indicating volunteering individuals are normalised by subtracting their mean value among the subpopulation of candidates with volunteering activities. Lastly, because two applicants contacted the same firm, their probability of receiving a positive reaction is correlated. Therefore, standard errors are corrected for the clustering of the observations at the vacancy level.

\section{TABLE 3 ABOUT HERE.}

In Model (1) and (5), we regress positive call-back on a dummy indicating only volunteer work. In line with the first row of Panel A and Panel B of Table 2, we see that volunteering increases positive call-back in a broad sense with 7.3 percentage points and positive call-back in a strict sense with 2.8 percentage points. ${ }^{15}$

In Model (2) and (6), we add interactions between volunteer work and the variables by which we broke down our data in the lower rows of Panel A and Panel B of Table 2. More concretely, we add interactions with indicators of high-educated candidates, male candidates, candidates who reveal engagement in a cancer organisation, candidates who reveal engagement at a korfball sports club, candidates with two engagements, and candidates with three engagements. For both call-back outcomes, we find a significant interaction only with respect to gender: the male volunteering premium in terms of getting any positive reaction (an

\footnotetext{
${ }^{15}$ While the size of our sample is substantially lower than the size of the data gathered in some recent large-scale correspondence experiments in the United States such as Kroft et al. (2013) and Neumark et al. (2015), it is at least comparable to many other recent (and well-published) field experiments included in the review study of Baert (2017). In addition, a post hoc power analysis shows that based on the variation in our dataset, we were able to distinguish rather small effects from zero effects. For instance, an increase of the positive call-back rate in a broad sense with $4.7(\approx 1.96 \times 0.024 \times 100)$ percentage points could have been rejected at the $5 \%$ significance level.
} 
invitation to a job interview) is 11.8 (8.3) percentage points lower than the female premium. Again, this is perfectly in line with what is shown in Table $2 .{ }^{16}$ In addition, not surprisingly, we observe significantly higher positive call-back rates for the higheducated candidates (without interaction with volunteering).

In Model (3) and (7), we extend the set of variables included as such and in interaction with volunteering with two vacancy characteristics that may, due to the finite nature of our sample, correlate with the variables that were randomly assigned between the vacancies. These vacancy characteristics are (i) an indicator of vacancies in the public and non-profit sector ${ }^{17}$ and (ii) an indicator of vacancies posted by interim offices. Further, in Model (4) and (8), we add vacancy fixed effects to the specification of Model (3) and (7). ${ }^{18}$ The introduction of these additional controls hardly affects the aforementioned overall effect of disclosing volunteer work activities and the interaction effect with respect to gender.

To further test the robustness of the presented regression results, we also estimated (i) binary logit models and (ii) and an ordered logit model. ${ }^{19}$ We also performed analyses with triple interactions between volunteering, education level and gender, but these analyses turned out to be underpowered to provide additional insights. The results for these models led to the same empirical conclusions and are

\footnotetext{
${ }^{16}$ For instance, subtracting the male positive call-back difference of 1.4 percentage points from the female positive call-back difference of 13.2 shown in Panel A of Table 2, yields 11.8 .

17 Traditionally, the rate of volunteer participation has been found to be higher in the public and non-profit sector than in the private sector (Bandiera, 2014; Prouteau and Wolff, 2006; Rotolo and Wilson, 2006). It remains unclear whether this phenomenon is because prosocial employees are attracted to the societal goals of non-commercial organisations and, ipso facto, sort themselves into these organisations, or whether employers in the public and nonprofit sector are more likely than for-profit employers to rely on intrinsically (socially) motivated employees because of their unique organisational needs, with a strong desire for the generation of social benefits (Anderson et al., 2004; Bandiera et al., 2011; Baron and Hannan, 2002; Francois and Vlassopoulos, 2008; Jacobsen et al., 2011; Kolstad and Lindkvist, 2013; Leete, 2000; Schneider, 1987).

${ }^{18}$ In these models, the variables without an interaction with volunteering are saturated (as they are constant at the vacancy level).

${ }^{19}$ The outcome variable of this model is 2 in cases in which the candidate is immediately invited to a job interview, 1 in cases in which she/he receives any other (broad-sense) positive reaction, and 0 in cases in which she/he receives no positive reaction at all.
} 
available upon request.

\section{Conclusion}

In this study, we contributed to the literature on the returns to volunteering in the labour market. Whereas all previous contributions to this literature relied on observational data to estimate the effect of volunteering on income, we adopted a field experimental approach to investigate its impact on hiring chances. More concretely, we sent pairs of fictitious job applications to genuine vacancies in Belgium. For every vacancy, a treatment of volunteering was randomly assigned to one pair member. By analysing employers' call-back, we found that the causal effect of disclosing volunteering activities on hiring opportunities is, both in statistical and economic terms, substantial. Volunteering candidates were found to have a 7.3 percentage points higher probability of receiving any positive reaction and a 2.8 percentage points higher probability of being immediately invited for a job interview. So, our findings turned out to be fully consistent with the previous contributions to this literature, all of which provided evidence for a substantial positive effect of volunteer work on income.

Because in addition to the within-pair randomisation of volunteering, the female or male gender and different combinations of three types of volunteering were randomly assigned between our pairs of fictitious job applicants, we were able to estimate heterogeneity in the volunteering premium by the gender of the candidate and her/his dose of volunteering. We found that women had larger returns to volunteer experience than men. This contrasts to what was found in contributions on the volunteering premium in income. An explanation for these diverging results might be that the higher volunteering premium for men found based on observational data may merely reflect the fact that males select themselves into types of volunteering that are more rewarded in the labour market (such as service 
clubs). ${ }^{20}$

We end by acknowledging three research limitations inherent to our study design. The most important limitation of this study is its focus on a particular-but determining-labour market outcome, i.e. the initial hiring decisions of employers (outside candidates' network). Because we simply investigate effects on first callbacks, we cannot translate our findings into divergences in final job offers (let alone in wages or income). However, Bertrand and Mullainathan (2004) have argued that one can expect that reduced interview rates translate into reduced job offers as employers are expected to invite only job candidates with a fair chance of finally getting the job.

A second limitation has further repercussions for the generalisability of our findings. We measure only the (potential) surplus of volunteering for young candidates within jobs in administrative and commercial occupations submitted to the Public Employment Agency of Flanders. Although compared to former correspondence experiments (see Section 2.1), this limitation is less acute in our design, it is still possible that the surplus of volunteering is more or less present in other occupations than those covered in our study. In particular, as we focus on white-collar jobs, our results cannot be easily generalised to blue-collar jobs. For instance, personality traits related to volunteering such as extraversion and openness might be more relevant in white-collar than in blue-collar jobs and, as a consequence, result in a lower volunteering premium in the latter jobs. However, because this limitation should cause a similar shift in the volunteering surplus irrespective of candidate characteristics, this fact should not bias the conclusions with respect to heterogeneity in the surplus of volunteering by, for instance, the gender of the candidate. The same is true for the first mentioned limitation.

Third, our experimental setting does not allow us to disentangle the mechanisms

\footnotetext{
20 Day and Devlin (1997) and Dittrich and Mey (2015) show, indeed, that women in Canada and Germany spend more time performing volunteer work at religious organisations or organisations that help the poor or the elderly, whereas men are more active in recreational organisations and service clubs, such as the Rotary Club. Exploratory analyses by Day and Devlin (1997) indicate that the latter types of volunteering are more rewarded in the labour market.
} 
underlying the volunteering premium. Because strict equivalence between our fictitious applicants was ensured and because, by construction, they applied for positions with an employer outside their network, the positive treatment effects can only be explained by employer side preferences and perceptions. However, these preferences and perceptions may relate to all three theoretical channels for a volunteering premium mentioned in the introduction. On the one hand, employers may have a taste for collaboration with prosocial employees and/or believe that their other employees' or customers have a taste in this respect. On the other hand, they may derive human capital and/or social capital related characteristics from volunteering on one's résumé. ${ }^{21}$ In our opinion, exploring the relative importance of these mechanisms is the logical next step to take in this literature. Also from a societal point of view it would be interesting to know why exactly volunteering does pay-off in the labour market as policy makers who want to stimulate volunteering in their society could use this information in motivating campaigns.

\section{Compliance with Ethical Standards}

This research was reviewed and approved by the Ethical Committee of the Faculty of Economics and Business Administration of Ghent University at its meeting of 9 July 2013.

The authors declare that they have no conflict of interest.

\section{References}

Ahmed, A. M., Andersson, L., Hammarstedt, M. (2012): Does age matter for

\footnotetext{
${ }^{21}$ In addition, volunteering might be related to personality traits such as emotional stability, extraversion and openness, as mentioned in Section 1
} 
employability? A field experiment on ageism in the Swedish labour market. Applied Economics Letters, 19, 403-406.

Albert, A., Escot, L., Fernández-Cornejo, J. A. (2011): A field experiment to study sex and age discrimination in the Madrid labour market. International Journal of Human Resource Management, 22, 351-375.

Anderson, N., Lievens, F., Van Dam, K., Ryan, A. M. (2004): Future perspectives on employee selection: Key directions for future research and practice. Applied Psychology, 53, 487-501.

Arrow, K. J. (1973): The Theory of Discrimination. In Ashenfelter, O., Rees, A. (eds.): Discrimination in Labor Markets. Princeton: Princeton University Press.

Baert, S. (2017): Hiring Discrimination: An Overview of (Almost) All Correspondence Experiments Since 2005. IZA Discussion Papers, 10738.

Baert, S., Cockx, B., Gheyle, N., Vandamme, C. (2015): Is There Less Discrimination in Occupations Where Recruitment Is Difficult? ILR Review, 68, 467500.

Baert, S., De Pauw, A.-S., Deschacht, N. (2016a): Do Employer Preferences Contribute to Sticky Floors? ILR Review, 69, 714-736.

Baert, S., Norga, J., Thuy, Y., Van Hecke, M. (2016b): Getting Grey Hairs in the Labour Market. A Realistic Experiment on Age Discrimination. Journal of Economic Psychology, 57, 86-101.

Baert, S., Rotsaert, O., Verhaest, D., Omey, E. (2016c): Student Employment and Later Labour Market Success: No Evidence for Higher Employment Chances. Kyklos, 69, 401-425.

Baert, S., Vujić, S. (2016): Immigrant Volunteering: A Way Out of Labour Market Discrimination? Economics Letters, 146, 95-98.

Bandiera, O. (2014) Incentives for Public Service Delivery. Keynote lecture at the Annual Conference of the European Association of Labour Economists of 2014.

Bandiera, O., Barankay, I., Rasul, I. (2011): Field Experiments with Firms. Journal of Economic Perspectives, 25, 63-82. 
Baron, J. N., Hannan, M. T. (2002): Organizational Blueprints for Success in HighTech Start-Ups: Lessons from the Stanford Project on Emerging Companies. California Management Review, 44, 7-36.

Barrick, M. R., Mount, M. K. (1991): The big five personality dimensions and job performance: a meta-analysis. Personnel Psychology, 44, 1-26.

Becker, G. S. (1957): The Economics of Discrimination. Chicago: University of Chicago Press.

Becker, G. S. (1964). Human Capital: A Theoretical and Empirical Analysis, with Special Reference to Education. New York: National Bureau of Economic Research.

Becker, G. S. (1965): A theory of the allocation of time. Economic Journal, 75, 493-517.

Bekkers, R. (2005): Participation in voluntary associations: Relations with resources, personality, and political values. Political Psychology, 26, 439-454.

Bertrand, M., Mullainathan, S. (2004): Are Emily and Greg more employable than Lakisha and Jamal? A field experiment on labor market discrimination. American Economic Review, 94, 991-1013.

Besley, T., Ghatak, M. (2005): Competition and incentives with motivated agents. American Economic Review, 95, 616-636.

Binder, M., Freytag, A. (2013): Volunteering, subjective well-being and public policy. Journal of Economic Psychology, 34, 97-119.

Booth, A. L., Leigh, A. (2010): Do employers discriminate by gender? A field experiment in female-dominated occupations. Economics Letters, 107, 236-238.

Borghans, L., ter Weel, B., Weinberg, B. A. (2008): Interpersonal Styles and Labour Market Outcomes. Journal of Human Resources, 43, 815-858.

Carpenter, J. P., Myers, C. K. (2010): Why Volunteer? Evidence on the Role of Altruism, Reputation, and Incentives. Journal of Public Economics, 94, 911-920.

Costa, P.T. Jr., McCrae, R. R. (1992): Revised NEO Personality Inventory (NEO-PIR) and NEO Five-Factor Inventory (NEO-FFI) manual. Odessa: Psychological 
Assessment Resources.

Cozzi, G., Mantovan, N., Sauer, R. M. (in press): Does It Pay to Work for Free? Wage Returns and Gender Differences in the Market for Volunteers. Oxford Bulletin of Economics and Statistics. DOI: 10.1111/obes.12183.

Day, K. M., Devlin, R. A. (1997): Can volunteer work help explain the male-female earnings gap? Applied Economics, 29, 707-721.

Day, K. M., Devlin, R. A. (1998): The payoff to work without pay: volunteer work as an investment in human capital. Canadian Journal of Economics, 31, 1179-1191.

Dittrich, M., Mey, B. (2015): Gender differences in volunteer activities: Evidence from German survey data. Economics Bulletin, 35, 349-360.

Elshaug, C., Metzer, J. (2001): Personality and volunteering: A review of the literature. Journal of Social Psychology, 141, 752-763.

Eriksson, S., Rooth, D.-O. (2014): Do Employers Use Unemployment as a Sorting Criterion When Hiring? Evidence from a Field Experiment. American Economic Review, 104, 1014-1039.

Fortin, N. M. (2008): The Gender Wage Gap among Young Adults in the United States: The Importance of Money versus People. Journal of Human Resources, 43, 884-918.

Francois, P., Vlassopoulos, M. (2008): Pro-social motivation and the delivery of social services. CESifo Economic Studies, 54, 22-54.

Granovetter, M. S. (1973): The Strength of Weak Ties. American Journal of Sociology, 78, 1360-1380.

Gregg, P., Grout, P. A., Ratcliffe, A., Smith, S., Windmeijer, F. (2011): How important is pro-social behaviour in the delivery of public services? Journal of Public Economics, 95, 758-766.

Hackl, F., Halla, M., Pruckner, G. J. (2007): Volunteering and Income - The Fallacy of the Good Samaritan? Kyklos, 60, 77-104.

Heineck, G. (2011): Does it Pay to Be Nice? Personality and Earnings in the United 
Kingdom. ILR Review, 64, 1020-1038.

Jacobsen, K., Eika, K., Helland, L., Lind, J., Nyborg, K. (2011): Are nurses more altruistic than real estate brokers? Journal of Economic Psychology, 32, 818-831.

Jacquemet, N., Yannelis C. (2012): Indiscriminate discrimination: a correspondence test for ethnic homophily in the Chicago labor market. Labour Economics, 19, 824-832.

Kaas, L., Manger, C. (2012): Ethnic Discrimination in Germany's Labour Market: A Field Experiment. German Economic Review, 13, 1-20.

Kolstad, J. R., Lindkvist, I. (2013): Pro-social preferences and self-selection into the public health sector: evidence from an economic experiment. Health Policy and Planning, 28, 320-327.

Kroft, K., Lange, F., Notowidigdo, M. J. (2013): Duration Dependence and Labor Market Conditions: Evidence from a Field Experiment. Quarterly Journal of Economics, 128, 1123-1167.

Lagarde, M., Blaauw, D. (2014): Pro-social preferences and self-selection into jobs: Evidence from South African nurses. Journal of Economic Behavior \& Organization, 107, 136-152.

Lahey, J. N. (2008): Age, women, and hiring: an experimental study. Journal of Human Resources, 43, 30-56.

Leete, L. (2000): Wage equity and employee motivation in nonprofit and forprofit organizations. Journal of Economic Behavior \& Organization, 43, 423-446.

Meier, S., Stutzer, A. (2008): Is Volunteering Rewarding in Itself? Economica, 75, 39-59.

Mincer, J. (1958): Investment In Human Capital and the Personal Income Distribution. Journal of Political Economy, 66, 281-302.

Neumark, D., Burn, I., Button, P. (2015): Is it harder for older workers to find jobs? New and improved evidence from a field experiment. NBER Working Paper Series, 21669. 
OECD (2015): Skills for Social Progress. Paris: OECD.

Pager, D. (2007): The use of field experiments for studies of employment discrimination: contributions, critiques, and directions for the future. Annals of the American Academy of Political and Social Science, 609, 104-133.

Patacchini, E., Ragusa, G., Zenou, Y. (2015): Unexplored dimensions of discrimination in Europe: homosexuality and physical appearance. Journal of Population Economics, 28, 1045-1073.

Prouteau, L., Wolff, F.-C. (2006): Does volunteer work pay off in the labor market? Journal of Socio-Economics, 35, 992-1013.

Riach, P. A., Rich, J. (2002): Field Experiments of Discrimination in the Market Place. Economic Journal, 112, 480-518.

Riach, P. A., Rich, J. (2007): An Experimental Investigation of Age Discrimination in the Spanish Labour Market. IZA Discussion Papers, 2654.

Rotolo, T., Wilson, J. (2006): Employment sector and volunteering: the contribution of nonprofit and public sector workers to the volunteer labour force. Social Science Quarterly, 47, 21-40.

Sauer, R. M. (2015): Does it Pay for Women to Volunteer? International Economic Review, 56, 537-564.

Schneider, B. (1987): The people make the place. Personnel Psychology, 40, 437453.

Tett, R. P., Jackson, D. N., Rothstein, M. (1991): Personality measures as predictors of job performance: A meta-analytic review. Personnel Psychology, 44, 703-742.

Uysal, S. D., Pohlmeier, W. (2011): Unemployment duration and personality. Journal of Economic Psychology, 32, 980-992.

Weichselbaumer, D. (2004): Is it sex or personality? The impact of sex stereotypes on discrimination in applicant selection. Eastern Economic Journal, 30, 159-186. 
Wilson, J., Mantovan, N., Sauer, R. M. (2017): Volunteer Work as a SelfDevelopmental Strategy in an Age of Precarious Employment. Mimeo. 
Figure 1. Fraction of Individuals at Work for Voluntary or Charitable Organisations At Least Once Every Six Months by Country in Europe (in 2006/2007 and 2012/2013)

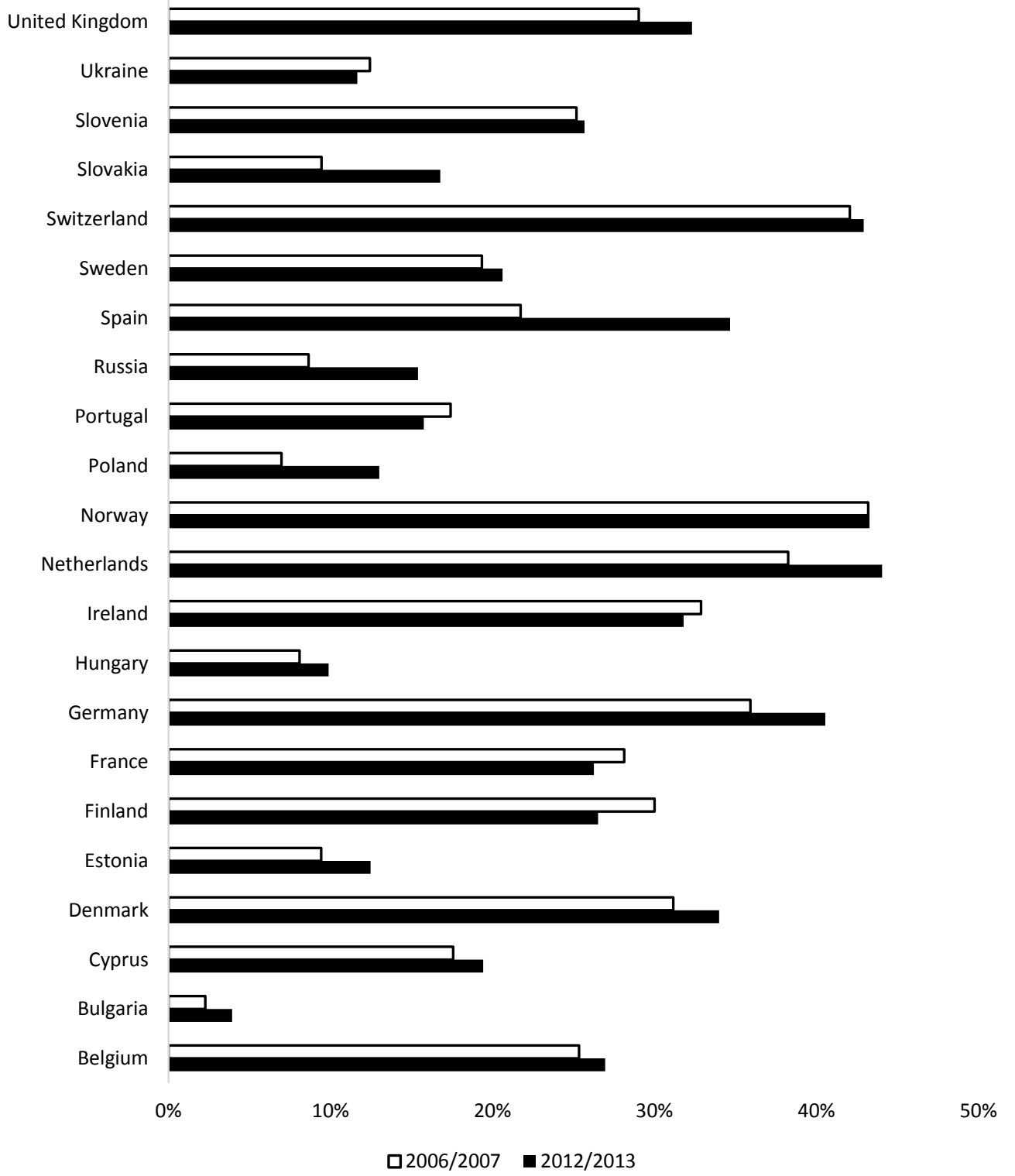

Notes. Source: Own calculations based on the question "In the past 12 months, how often did you get involved in work for voluntary or charitable organisations?" in the third round (conducted in 2006/2007) and sixth round (conducted in 2012/2013) of the European Social Survey. Only countries that were surveyed in both rounds are included. 
Table 1. Micro-Economic Returns to Volunteering in the Labour Market: Literature Review

\begin{tabular}{|c|c|c|c|}
\hline Study & $\begin{array}{l}\text { Country of } \\
\text { analysis }\end{array}$ & Main result(s) & Methodological approach \\
\hline $\begin{array}{l}\text { Cozzi et al. (in } \\
\text { press) }\end{array}$ & $\begin{array}{l}\text { United } \\
\text { Kingdom }\end{array}$ & $\begin{array}{l}\text { A (past or current) volunteering activity increases current and future wages by } 45.5 \% \\
\text { for men and } 38.3 \% \text { for women. OLS estimates yield substantially lower returns. }\end{array}$ & $\begin{array}{l}\text { IV modelling (using rainfall across area districts as an instrument for volunteer } \\
\text { activity) and controlling for individual fixed effects on longitudinal family } \\
\text { survey data. }\end{array}$ \\
\hline $\begin{array}{l}\text { Day and Devlin } \\
\text { (1997) }\end{array}$ & Canada & $\begin{array}{l}\text { A (past or current) volunteering activity increases current and future wages by } 21.5 \% \\
\text { for men and } 11.2 \% \text { for women. }\end{array}$ & $\begin{array}{l}\text { OLS regressions controlling for observables on cross-sectional survey data of } \\
\text { volunteer activity. }\end{array}$ \\
\hline $\begin{array}{l}\text { Day and Devlin } \\
\text { (1998) }\end{array}$ & Canada & $\begin{array}{l}\text { A (past or current) volunteering activity in the current year increases earnings in this } \\
\text { year by } 6.6 \% \text {. }\end{array}$ & $\begin{array}{l}\text { OLS regressions controlling for observables on cross-sectional survey data of } \\
\text { volunteer activity. }\end{array}$ \\
\hline $\begin{array}{l}\text { Hackl et al. } \\
\text { (2007) }\end{array}$ & Austria & A current volunteering activity increases current earnings by $18.5 \%$. & $\begin{array}{l}\text { IV modelling (using engagement in a club during youth and having a } \\
\text { volunteering partner as an instrument for volunteer activity) on cross-sectional } \\
\text { family survey data. }\end{array}$ \\
\hline $\begin{array}{l}\text { Prouteau and } \\
\text { Wolff (2006) }\end{array}$ & France & $\begin{array}{l}\text { A current volunteering activity (in which one performs managerial tasks) increases } \\
\text { current earnings by } 5.5 \% \text { in the public sector and decreases current earnings by } 1.7 \% \\
\text { in the private sector. }\end{array}$ & $\begin{array}{l}\text { Bivariate probit estimations with endogenous switching on cross-sectional } \\
\text { family time allocation survey data. }\end{array}$ \\
\hline Sauer (2015) & $\begin{array}{l}\text { United } \\
\text { States }\end{array}$ & $\begin{array}{l}\text { An extra year of (past or current) volunteering activity increases wage offers in future } \\
\text { full-time (part-time) work by } 2.6 \%(8.5 \%) \text { for women between age } 25 \text { and } 55 \text {. }\end{array}$ & $\begin{array}{l}\text { Structural modelling (discrete choice dynamic programming) on longitudinal } \\
\text { family survey data. }\end{array}$ \\
\hline $\begin{array}{l}\text { Wilson et al. } \\
\text { (2017) }\end{array}$ & $\begin{array}{l}\text { United } \\
\text { Kingdom }\end{array}$ & $\begin{array}{l}\text { A current volunteering activity increases current income by } 6.2 \% \text { for men and } 4.1 \% \\
\text { for women. }\end{array}$ & Individual fixed effects regressions on longitudinal family survey data. \\
\hline
\end{tabular}


Table 2. Positive Call-Back in a Broad Sense by Volunteer Status

\begin{tabular}{|c|c|c|c|c|}
\hline (1) & $(2)$ & (3) & (4) & (5) \\
\hline \multirow[b]{2}{*}{ Data selection } & \multirow[b]{2}{*}{ Jobs } & \multicolumn{2}{|c|}{ Positive call-back rate } & \multirow{2}{*}{$\begin{array}{l}\text { Positive call-back difference } \\
\qquad(3)-(4)\end{array}$} \\
\hline & & $\begin{array}{l}\text { Volunteer } \\
\text { candidate }\end{array}$ & $\begin{array}{c}\text { Control } \\
\text { candidate }\end{array}$ & \\
\hline \multicolumn{5}{|l|}{ A. Positive call-back in a broad sense } \\
\hline All & 288 & 0.229 & 0.156 & $0.073 * * *[3.043]$ \\
\hline Middle-educated & 144 & 0.118 & 0.069 & $0.049 *[1.961]$ \\
\hline High-educated & 144 & 0.340 & 0.243 & $0.097 * *[2.371]$ \\
\hline Female gender & 144 & 0.319 & 0.188 & $0.132 * * *[3.224]$ \\
\hline Male gender & 144 & 0.139 & 0.125 & $0.014[0.576]$ \\
\hline Volunteer at life-saving food provider & 176 & 0.239 & 0.153 & $0.085^{* * *}[2.656]$ \\
\hline Volunteer at cancer foundation & 176 & 0.233 & 0.142 & $0.091^{* * *}[3.097]$ \\
\hline Volunteer at sports club & 176 & 0.233 & 0.188 & $0.045[1.517]$ \\
\hline One volunteering activity & 96 & 0.219 & 0.135 & $0.083^{*}[1.912]$ \\
\hline Two volunteering activities & 144 & 0.222 & 0.167 & $0.056 *[1.717]$ \\
\hline Three volunteering activities & 48 & 0.271 & 0.167 & $0.104 *[1.699]$ \\
\hline \multicolumn{5}{|l|}{ B. Positive call-back in a strict sense } \\
\hline Full sample & 288 & 0.111 & 0.083 & $0.028 *[1.711]$ \\
\hline Middle-educated & 144 & 0.056 & 0.042 & $0.014[1.000]$ \\
\hline High-educated & 144 & 0.167 & 0.125 & $0.042[1.419]$ \\
\hline Female gender & 144 & 0.181 & 0.111 & $0.069 * *[2.396]$ \\
\hline Male gender & 144 & 0.042 & 0.056 & $-0.014[1.000]$ \\
\hline Volunteer at life-saving food provider & 176 & 0.125 & 0.097 & $0.028[1.294]$ \\
\hline Volunteer at cancer foundation & 176 & 0.102 & 0.074 & $0.028[1.390]$ \\
\hline Volunteer at sports club & 176 & 0.108 & 0.091 & $0.017[0.831]$ \\
\hline One volunteering activity & 96 & 0.104 & 0.073 & $0.031[1.136]$ \\
\hline Two volunteering activities & 144 & 0.118 & 0.083 & $0.035[1.514]$ \\
\hline Three volunteering activities & 48 & 0.104 & 0.104 & $0.000[0.000]$ \\
\hline
\end{tabular}

Notes. The t-test for the positive call-back difference tests the null hypothesis that the positive call-back rates are the same for volunteer and control candidates. ${ }^{* * *}\left(* * ;{ }^{*}\right)$ indicates significance at the $1 \%(5 \% ; 10 \%)$ significance level. T-values are bracketed. 


\section{Table 3. Regression Analysis}

\begin{tabular}{|c|c|c|c|c|c|c|c|c|}
\hline & (1) & (2) & (3) & (4) & (5) & (6) & (7) & (8) \\
\hline Volunteering & $\begin{array}{c}0.073 * * * \\
(0.024)\end{array}$ & $\begin{array}{c}0.073 * * * \\
(0.024)\end{array}$ & $\begin{array}{c}0.073 * * * \\
(0.024)\end{array}$ & $\begin{array}{c}0.073 * * * \\
(0.024)\end{array}$ & $\begin{array}{l}0.028^{*} \\
(0.016)\end{array}$ & $\begin{array}{l}0.028^{*} \\
(0.016)\end{array}$ & $\begin{array}{l}0.028^{*} \\
(0.016)\end{array}$ & $\begin{array}{l}0.028^{*} \\
(0.016)\end{array}$ \\
\hline Volunteering $\times$ High-educated (normalised) & & $\begin{array}{c}0.049 \\
(0.048)\end{array}$ & $\begin{array}{c}0.038 \\
(0.049)\end{array}$ & $\begin{array}{c}0.039 \\
(0.049)\end{array}$ & & $\begin{array}{c}0.028 \\
(0.032)\end{array}$ & $\begin{array}{c}0.025 \\
(0.030)\end{array}$ & $\begin{array}{c}0.025 \\
(0.029)\end{array}$ \\
\hline Volunteering $\times$ Male gender (normalised) & & $\begin{array}{c}-0.118^{* *} \\
(0.048)\end{array}$ & $\begin{array}{c}-0.113^{* *} \\
(0.048)\end{array}$ & $\begin{array}{c}-0.113^{* *} \\
(0.047)\end{array}$ & & $\begin{array}{c}-0.083^{* *} \\
(0.032)\end{array}$ & $\begin{array}{c}-0.082^{* *} \\
(0.032)\end{array}$ & $\begin{array}{c}-0.082^{* *} \\
(0.032)\end{array}$ \\
\hline Volunteering $\times$ Volunteer at cancer foundation (normalised) & & $\begin{array}{l}-0.013 \\
(0.062)\end{array}$ & $\begin{array}{l}-0.007 \\
(0.062)\end{array}$ & $\begin{array}{c}0.018 \\
(0.060)\end{array}$ & & $\begin{array}{l}-0.050 \\
(0.051)\end{array}$ & $\begin{array}{l}-0.050 \\
(0.051)\end{array}$ & $\begin{array}{c}0.002 \\
(0.037)\end{array}$ \\
\hline Volunteering $\times$ Volunteer at sports club (normalised) & & $\begin{array}{l}-0.013 \\
(0.063)\end{array}$ & $\begin{array}{l}-0.010 \\
(0.064)\end{array}$ & $\begin{array}{l}-0.086 \\
(0.065)\end{array}$ & & $\begin{array}{l}-0.038 \\
(0.047)\end{array}$ & $\begin{array}{l}-0.038 \\
(0.047)\end{array}$ & $\begin{array}{l}-0.025 \\
(0.045)\end{array}$ \\
\hline Volunteering $x$ Two volunteering activities (normalised) & & $\begin{array}{c}0.012 \\
(0.061)\end{array}$ & $\begin{array}{c}0.013 \\
(0.061)\end{array}$ & $\begin{array}{c}0.000 \\
(0.063)\end{array}$ & & $\begin{array}{c}0.043 \\
(0.047)\end{array}$ & $\begin{array}{c}0.044 \\
(0.047)\end{array}$ & $\begin{array}{c}0.013 \\
(0.044)\end{array}$ \\
\hline Volunteering $\times$ Three volunteering activities (normalised) & & $\begin{array}{c}0.069 \\
(0.102)\end{array}$ & $\begin{array}{c}0.071 \\
(0.102)\end{array}$ & $\begin{array}{c}0.072 \\
(0.100)\end{array}$ & & $\begin{array}{c}0.058 \\
(0.073)\end{array}$ & $\begin{array}{c}0.058 \\
(0.074)\end{array}$ & $\begin{array}{l}-0.014 \\
(0.069)\end{array}$ \\
\hline Volunteering $\times$ Public and non-profit sector (normalised) & & & $\begin{array}{l}-0.053 \\
(0.064)\end{array}$ & $\begin{array}{l}-0.055 \\
(0.062)\end{array}$ & & & $\begin{array}{l}-0.016 \\
(0.017)\end{array}$ & $\begin{array}{l}-0.018 \\
(0.017)\end{array}$ \\
\hline Volunteering $\mathrm{x}$ Interim office as posting agency (normalised) & & & $\begin{array}{c}0.073 \\
(0.102)\end{array}$ & $\begin{array}{c}0.073 \\
(0.101)\end{array}$ & & & $\begin{array}{c}0.020 \\
(0.085)\end{array}$ & $\begin{array}{c}0.022 \\
(0.085)\end{array}$ \\
\hline High-educated (normalised) & & $\begin{array}{c}0.174 * * * \\
(0.042)\end{array}$ & $\begin{array}{c}0.172^{* * *} \\
(0.044)\end{array}$ & & & $\begin{array}{c}0.083^{* *} \\
(0.032)\end{array}$ & $\begin{array}{c}0.086^{* * *} \\
(0.033)\end{array}$ & \\
\hline Male gender (normalised) & & $\begin{array}{l}-0.063 \\
(0.042)\end{array}$ & $\begin{array}{l}-0.065 \\
(0.043)\end{array}$ & & & $\begin{array}{l}-0.056^{*} \\
(0.032)\end{array}$ & $\begin{array}{l}-0.056^{*} \\
(0.034)\end{array}$ & \\
\hline Public and non-profit sector (normalised) & & & $\begin{array}{c}0.051 \\
(0.080)\end{array}$ & & & & $\begin{array}{c}0.001 \\
(0.053)\end{array}$ & \\
\hline Interim office as posting agency (normalised) & & & $\begin{array}{c}0.009 \\
(0.083)\end{array}$ & & & & $\begin{array}{l}-0.023 \\
(0.057)\end{array}$ & \\
\hline Intercept & $\begin{array}{c}0.156^{* * *} \\
(0.021) \\
\end{array}$ & $\begin{array}{c}0.156^{* * *} \\
(0.021) \\
\end{array}$ & $\begin{array}{c}0.156^{* * *} \\
(0.021) \\
\end{array}$ & $\begin{array}{c}0.156^{* * *} \\
(0.021) \\
\end{array}$ & $\begin{array}{c}0.083^{* * *} \\
(0.016) \\
\end{array}$ & $\begin{array}{c}0.083^{* * *} \\
(0.016) \\
\end{array}$ & $\begin{array}{c}0.083^{* * *} \\
(0.016) \\
\end{array}$ & $\begin{array}{c}0.083^{* * *} \\
(0.016) \\
\end{array}$ \\
\hline Vacancy fixed effects & No & No & No & Yes & No & No & No & Yes \\
\hline Outcome variable: Positive call-back in a broad sense & Yes & Yes & Yes & Yes & No & No & No & No \\
\hline Outcome variable: Positive call-back in a strict sense & No & No & No & No & Yes & Yes & Yes & Yes \\
\hline Observations & 576 & 576 & 576 & 576 & 576 & 576 & 576 & 576 \\
\hline
\end{tabular}

Notes. The presented statistics are coefficients and standard errors based on linear probability model estimates. All independent variables except for the volunteer indicator, are normalised by subtracting their mean value among the subpopulation of candidates with volunteering activities. Standard errors, corrected for clustering at the vacancy level, are between parentheses. ${ }^{* * *}(* * ; *)$ indicates significance at the $1 \%(5 \% ; 10 \%)$ significance level. 